\title{
Institutional Strengthening in Waste Management in Medan, Binjai, Deli Serdang, Karo (Mebidangro)
}

\author{
Hatta Ridho', M. Arif Nasution², Subhilhar ${ }^{3}$, Muryanto Amin ${ }^{4}$ \\ 1,2,3,4 University of Sumatera, Indonesia \\ hattaridho@usu.ac.id,arifnasution2010@yahoo.com,subhilhar.politik@gmail.com,muryantoamin@usu.ac.id
}

\begin{abstract}
Weak coordination can also be seen in the achievement of cooperation agreements between regions in the Mebidangro area. For example, how the weak coordination between Pemko Medan and Pemko Deli Serdang resulted in the closure of the TPA Namo Bintang in Pancur Batu sub-district, even though Presidential Decree No. 62/2011 has designated TPA Namo Bintang together with TPAatuh in Medan Marelan as a garbage landfill for residents of Medan city. Weak coordination certainly requires institutional strengthening that can ensure synergy among government ranks in the Mebidangro area to be able to overcome problems faced together. This research was conducted in the Mebidangro area by using qualitative which focused on the problems that existed at the time of the research or the actual problems as well as the facts about the problems being investigated as they were, accompanied by sufficient rational interpretation. Data collection techniques through observation, interviews and limited group discussions. The character of the Mebidangro implementing organs has not shown an orderly working mechanism, where the two main components of the character of the implementing organs, namely the SOP and the division of tasks / authorities between the provincial government and district / city governments as well as between district / city governments throughout the Mebidangro region do not exist. Institutional strengthening is needed to strengthen the Integrated Management Institution model.
\end{abstract}

Keywords institutional strengthening, mebidangra, waste area

\section{Introduction}

Although the Medan - Binjai - Deli Serdang - Karo Urban National Strategic Area (Mebidangro) has been ratified by Presidential Decree No. 62 of 2011 concerning the Urban Spatial Plan for Medan, Binjai, Deli Serdang and Karo, however, its development shows negative characteristics. Some of them: high urbanization, increasing congestion points where there are more than 20 congestion points, and decreasing environmental conditions are problems currently facing Mebidangro city.

Weak coordination can also be seen in the achievement of cooperation agreements between regions in the Mebidangro area. For example, how weak coordination between Pemko Medan and Pemko Deli Serdang resulted in the closure of TPA Namo Bintang in Pancur Batu sub-district, even though Presidential Decree No. 62/2011 has designated TPA Namo Bintang and TPA Waterfall in Medan Marelan sub-district as garbage landfill for residents of Medan city. The reason for this is that the same perception has not been achieved between the two parties regarding the technical aspects of financing the development and operation of TPA Namo Bintang, as well as aspects of waste processing methods that are deemed to be detrimental to Deli Serdang in Adipura's assessment. The 
Deli Serdang Regency Government thinks that it is only obliged to provide landfill in its area and hopes that the Medan Government will bear the development costs and operational costs, however, Pemko Medan does not have discretion to allocate APBD outside its administrative boundaries. As a comparison, we do not encounter this problem in the handling of garbage for DKI Jakarta residents at the Bantar Gebang TPA, Bekasi, West Java.

From the results of Nagai's research, the lack of responsiveness of the local government (lack of political will) can be seen from the lack of written agreements or regulations (Regional Regulations). Presidential Decree 62 of 2011this is still the only legal document underlying the Mebidangro scheme. There is no other official MoU issued by the Regent / Mayor or Governor; no office or coordinating body was even set up. While SKPD officials in North Sumatra Province acknowledge the goodness and benefits of cooperation between regions, the North Sumatra Provincial Government also assesses that there seems to be an atmosphere of suspicion and jealousy directed at Medan City by the other three districts / cities (Nagai, 2015).

The opportunity to put forward a new model in the implementation of inter-regional cooperation in the development of the Mebidangro area became open after the issuance of Law No. 23 of 2014 concerning Regional Government as a substitute for Law No. 32 of 2004. The opportunity referred to is a change in the authority of the Governor, where there is greater discretion. For the Governor to carry out the function of coordination and supervision for the implementation of development across districts / cities in his region compared to the previous era of the Regional Autonomy Law, so it is hoped that there will be strengthening in terms of priorities and strategies for the success of inter-regional cooperation. Of course, in this case, institutional strengthening is needed to build synergy in the Mebidangro area.

\section{Research Methods}

This research was conducted in the Mebidangro area by using qualitative which focused on the problems that existed at the time of the research or the actual problems as well as the facts about the problems being investigated as they were, accompanied by sufficient rational interpretation. Data collection techniques through observation, interviews and limited group discussions.

The analysis is carried out by giving additional weight to the understanding of the phenomenon under study based on personal views, comparisons with previous studies, or a combination of both. Then, the final form of interpreting the findings by researchers is to conceptualize (inductive)

\section{Results and Discussion}

Institutional strengthening cannot be separated from the improvement of existing regulations. Technically, the Mebidangro law is only regulated in Presidential Decree No. 62 of 2011 regarding the National Spatial Policy which places Metropolitan Mebidangro as a National Activity Center (PKN) as well as a National Strategic Area (KSN) with a focus on developing economic activities. In relation to cooperation between regions such as; Medan City, Binjai City, Deli Serdang Regency and Karo Regency have three strategic issues that must be identified and then studied and addressed, namely first, fixing the role of North Sumatra Province in carrying out inter-regional cooperation functions or "local government cooperation" which involves directly between regions -regional. 
Then the second technically determines directly the fields that can be or should be cooperated between regional cities / regencies. As well as the third, choosing models of cooperation that are in accordance with the nature of these fields. These issues are considered strategic because their position will determine the success of cooperation between local governments in the future, especially those that are directly related to the needs and interests of the community.

Formally, Sumatra Province was given a significant role in carrying out cooperation between regions in Mebidangro. The authority of North Sumatra Province as an autonomous region has been regulated by Government Regulation Number 25 of 2000 , which includes authority in cross-regency / municipal government fields as well as certain other governmental fields. This authority covers the fields of agriculture, maritime affairs, mining and energy, forestry and plantations, industry and trade, cooperatives, investment, manpower, health, education and culture, social, spatial planning, settlement, public works, transportation, the environment, politics in state and public administration, development of regional autonomy, financial balance, and the field of law and legislation.

In an effort to exercise this authority, the Province of North Sumatra does not only play a role as implementer and regulator of this sector directly and across districts / cities, the regions that are included in the Mebidangro scheme. However, it also provides support / assistance for cooperation between districts / cities in certain fields such as the development of regional infrastructure and facilities, investment, industry and trade, agriculture, and so on. Thus formally, cooperation between districts / cities must be regulated or facilitated by the province intensively, effectively and efficiently.

Moreover, in the Government Regulation related to institutional cooperation under the same province, it is also stated that Regencies / Cities that are not or have not been able to carry out one or more authorities can exercise this authority through cooperation between Regencies / Cities, cooperation between Regencies / Cities and the Province of Sumatra. North, or hand over such authority to the Province. And the implementation of authority through cooperation or handover of authority to the Province must be based on a Regency / City Regional Head Decree with the approval of the Regency / City Regional People's Representative Council (see Government Regulation Number 25 Year 2000, Article 4, points a and b).

However, the provisions regarding the role of North Sumatra Province according to Government Regulation Number 25 of 2000 are often criticized because the transfer of authority to this Province does not take into account the level of capacity of the Province, which in reality varies well. This can cause serious problems because theoretically a handover of authority to a party that does not consider the ability of the party concerned, then the handover will be a source of problems in the future (Keban, 2004: 115).

According to Daryono in Dewi (2018) the policies made by the government must have a clear strategy, ideally covering the following four things: (1) Policies to promote opportunities, (2) community empowerment policies, (3) capacity building policies , (4) Social protection policies. Besides having a clear strategy, a policy must contain the following principles: siding with the poor, based on the demand of the poor (demand driver), a policy made not to be kept secret, accountability, sustainable responsive, competent, participatory, integrated, targeted, decentralized, democratic, collaborating through networks, and law enforcement.

In reality, the level of ability of North Sumatra Province to provide cooperation support in the fields of agriculture, industry and trade, investment, development of regional infrastructure and facilities, arrangement of agreements on spatial planning, and settlement of disputes between regencies / cities, is also not yet known which causes a it is imperative 
that the Province of North Sumatra must make regional regulations in overcoming problems that can be resolved territorially across cities or districts in the Province of North Sumatra. Identification and planning in the Mebidangro concept involving the Province of North Sumatra regarding the areas that have been cooperated so far have rarely been carried out, unless there is an emergency problem that demands immediate treatment such as;

It must also be admitted, so far, that cooperation between regions (regencies-cities, cities, regencies, regencies / cities-provinces) in North Sumatra Province has not been perceived as a need so that it is not taken into account in the planning process which is very urgent. In fact, various problems or internal decisions of a City / Regency or Province are often related to problems or decisions outside its territorial boundaries that must be made without waiting for a long time. Likewise, there are many problems in a location or area in North Sumatra Province that arise because of policies originating from other regions, such as sanitation, crime, population, education, health, and waste problems in Medan City.

A public policy made by one City or Regency often does not take into account the impact on another City or Regency which should be handled through the government of North Sumatra Province. Cooperation between LGs under the Province of North Sumatra in Mebidangro is one of the options faced by the Regional Government which is very strong conceptually if implemented. Although, it must also be admitted, not all problems and services in the regions must be resolved through a cooperation scheme between local governments.

Only certain problems and services are resolved or resolved through cooperation in the North Sumatra Province. For that, certain considerations are needed. An effective way to determine these needs is to study the nature of the problems faced or the perceived needs by using the principle of "demand driven", namely whether a problem arises from outside the administrative area of the North Sumatra Provincial Government and has had a serious impact into the administrative area. North Sumatra Provincial Government, or whether a problem arises from within an administrative area of the North Sumatra Provincial Government and has had a serious impact outside the administrative areas of other Regional Government.

The solution is of course by strengthening institutions that previously had to go through conducting surveys, direct field visits, hearing various complaints of affected residents, conducting focus group discussions and assessing the seriousness of impacts in the North Sumatra Province. Because the purpose of Mebidangro collaboration is to increase sensitivity in see these various problems, with cooperation between regions. For that we need two important perspectives that see a local government in both an administrative and functional context in the Province of North Sumatra. Observing the problems faced within administrative boundaries is identifying various problems within local government areas that may have an impact beyond the regional government boundaries. Meanwhile, observing the problems faced within the functional area boundaries is identifying various problems across administrative areas. The identified problems must be aggregated and articulated to get the attention of the public, DPRD, and the executive, which in the future can make it easier to solve various problems.

So far, the cooperation models that can be chosen according to the nature of the fields being cooperated have not yet been identified broadly in North Sumatra Province. The unidentified reliable model has made it difficult to implement or realize cooperation between regions as demanded by Government Regulation Number 25 Year 2000. Therefore, it is necessary to initiate a model regarding cooperation between regions and 
sectors, which can then be used as an example. The discussion on cooperation models seems quite broad because it involves many forms of cooperation so that it is presented separately in a separate sub-discussion.

Meanwhile, strategic issuesrelating to the urgency of Cooperation between Regional Governments in North Sumatra Province has not yet received a focus of attention that cooperation between regions can be expected to be one of the innovative methods in improving the quality and coverage of public services.

Effectiveness and efficiency in the provision of facilities and infrastructure for public services such as education, health, clean water, and so on are also important issues, especially for underdeveloped areas. This increase in public services also includes infrastructure development. This infrastructure can include road networks, power plants, and so on. Even though it is related, cooperation between regions inNorth Sumatra ProvinceIn terms of security in the border area, it is also a strategic issue. Apart from security matters, cooperation in border areas is also focused on regional development, due to areas in urban areas.

Strengthening institutions in the linkage of spatial planning between regions in North Sumatra Province required in matters that can affect more than one area, such as watersheds (DAS), protected areas, and so on. Furthermore, institutional strengthening between regions inNorth Sumatra Province can be in the effort to overcome it disaster mitigation and post-disaster action, if we reflect on the experiences in NAD, Alor and Nabire, as well as other areas, it turns out that this situation requires good coordination and cooperation between neighboring areas.

Although there are several important points regarding Human Resources and limited capabilities, capacities and resources vary between regions North Sumatra Province giving rise to regional disparities and poverty (social inequality). However, through cooperation between Mebidangro regions, it is hoped that there will be an increase in regional capacity in optimizing resource use and local economic development, in order to reduce poverty and reduce regional disparities.

The argument about institutional strengthening, as has been done in South Korea and the United States regarding the Law on Regional Government, suggests the need to increase the role of the province, including in facilitating the resolution of problems between regions. For this reason, it is necessary to increase the capacity of the province in holding / encouraging cooperation between regions (local government cooperation). This role is primarily in the provincial capacity as an extension of the central government and as a facilitator and catalyst for Inter-Regional Cooperation (KAD).

Empirically, in many regions in various parts of the world the waste problem always involves inter-regional cooperation. Mainly overcoming the problem of waste as collection, transportation, processing, recycling or disposal and control of waste material which in turn forms a waste management system which consists of four main components, namely material production, collection and transportation, processing and reprocessing and placement. the end, namely to be recycled or end up in a landfill which is carried out in cooperation between regions, namely Medan City and Deli Serdang Regency.

This situation shows that the discourse on cooperation in waste management is not new, but has even been done since the existence of traditional humans. They already have their own system which is of course suitable to be applied to traditional societies that develop it jointly as well.

The waste management process with the Mebidangro concept will in turn be divided into types of waste which are separated based on their character or use value according to their respective needs. Law No. 18/2008 on Solid Waste Management regulates the 
responsibilities of central, provincial and municipal governments in Indonesia. The responsibilities of local governments at the city / regency level are to; a) establish policies and strategies for waste management based on national and provincial policies. b) carry out waste management. c) provide guidance and supervision to other parties on waste management. d) Build Temporary Waste Disposal Sites (TPS), Integrated Waste Management Sites (TPST) and Final Processing Sites (TPA) and (e) conduct monitoring and evaluation of TPA every 6 months every 20 years.

The approach used to handle waste at a higher level requires a more comprehensive conceptualization so that it requires a collaborative role in managing samaph with the concept of cooperation. The role of local government in the domain of waste management appears to illustrate the role of the state, namely in terms of planning through certain considerations such as improving the quality of life of people who were formerly laborintensive waste collectors, policy making, and implementing waste management through work contracts with technology-intensive companies develop in a comprehensive manner.

The policy of cooperation between the government of Medan City and Deli Serdang Regency is one of the important keys in seeing the role of waste management in general. Those actions taken by regional governments sometimes run independently without a concept or do not carry out regulations in accordance with Mebidangro. As a result of the situation, there are those who pay less attention to the communities affected by the planning. Government is not built to serve its own needs, but aims to serve the needs and interests of the community and create conditions that allow each member of the community to develop their abilities and creativity to achieve common goals (Perdana, 2019).

Government policy cannot be maximized if it is carried out alone without the support of various parties, especially stakeholders. In fact, collaboration and partnerships need to be carried out to get maximum waste management results which lead to the success of a region in overcoming the long problem of waste. Partnership or partnership is in principle built from cooperation carried out by certain parties in which the partnership has an association with participation between local governments.

Participation as stakeholders who take part in the management environment until decision making is used to build long-term capacity and increase the capacity of the community where this participation is used as a binding for the actors involved in the partnership which in this case have conceptually found direction and can be implemented with inter-agency cooperation under the authority of the North Sumatra Provincial Government. Furthermore, this partnership is a collaborative arrangement to achieve certain goals. The concept of partnership in waste management is a collaboration between the public sector as supervisor in waste management and the private sector as the implementer of waste management in Medan City.

The concept of partnership between private actors and public actors refers to the outcomes that are expected to have an effective impact in the waste management domain. Sumarto in Melyanti (2014: 193) describes partnership as a relationship that occurs between civil society, government and the private sector in order to achieve goals based on the principles of trust, equality and independence.

The form of this partnership can be found in the form of cooperation such as a waste bank. Junadi (2018: 2-7) hints at government interference in waste banks in Indonesia with the issuance of Minister of Environment Regulation Number 13 of 2012 which is the legal basis for the existence of waste banks. In addition, cooperation is also carried out with various business organizations as buyers of non-organic waste, reflecting the patron-client relationship between waste banks who are highly dependent on collectors. 
Territorially, based on a simple understanding at this time, waste management in Medan City is carried out with an individual pattern and is limited to commercial activities while domestic activities have not been carried out. These individual containers are placed in front of houses, buildings and shop houses along the road and the forms of containers used are various and vary according to their capacity.

In fact, these containers disturb the eye's eye because each house provides 1 unit of container made of woven bamboo baskets, used drums, containers of leftover paint and special trash containers made from permanent walls that are not closed. The impact is that if there are food scraps in the houses of Medan City residents, they are often entered by animals such as; cats, chickens to mice, so that the garbage scattered around the trash cans, which has an impact on the condition of the garbage that is scattered to the side of the road. This means that the containers provided by residents do not function as expected. This condition is caused by the non-standard container for landfills, for example for some shops, the size of the container is too small so that this container cannot be used properly.

Placement of garbage collection containers along the main road where there are many shops / shophouses in Medan City which are a source of waste generation. For traditional markets, communal containers are generally used, which are made of permanent walls, but due to the large volume of waste generated every day, the communal containers cannot accommodate the existing garbage. Sometimes garbage containers that are no longer suitable for use result in garbage being piled up in front of the market without using a container.

In the early situation, the Medan City Sanitation Office carried out garbage collection from each source of the generation on the protocol roads using direct transporters. Meanwhile, roads that cannot be traversed by pengut directly in residential areas are carried out by using garbage carts or garbage rickshaws. This activity is carried out 2 times a day, namely morning and afternoon.

Table 1. Number of Garbage Transporters in Medan City 2018

\begin{tabular}{|l|l|l|}
\hline No. & Type of Carrier & Number of units \\
\hline 1 & Container Truck & 16 \\
\hline 2 & Truck Arm Roll & 15 \\
\hline 3 & Drump Truck & 2 \\
\hline 4 & L300 Pick Up & 10 \\
\hline 5 & Typper Truck & 200 \\
\hline 6 & Truck Concaktor & 33 \\
\hline 7 & Road Sweeper Bil Up & 5 \\
\hline 8 & Road Sweeper Body & 7 \\
\hline 9 & Truck Toilet & 13 \\
\hline 10 & Stool Truck & 11 \\
\hline 11 & Socialization Truck & 1 \\
\hline 12 & Water Tank Truck & 3 \\
\hline 13 & Heavy equipment & 22 \\
\hline 14 & Trash Rickshaw & 276 \\
\hline & Amount & $\mathbf{5 7 6}$ \\
\hline
\end{tabular}

Source: Medan City Sanitation and Gardening Office 2019

Empirically, the process of waste collection and transportation activities in Medan City uses two methods, namely: first, it is carried out from the source of the generation (household waste) and is collected and transported by a garbage cart / rickshaw to the TPS 
that has been provided after which it is transported using an armroll truck to the final disposal site (TPA). Then, secondly, namely, from the source of the generation (household waste, shops, construction waste, markets) is transported using a Tripper truck directly to the final disposal site (TPA).

\section{Conclusion}

1. In carrying out the urban waste handling program, districts / cities in the Mebidangro area run independently without collaborating, either compulsory or voluntary cooperation. As a result, limited resources have caused urban waste not to be handled optimally in terms of technical waste management systems and environmental impacts, especially experienced by the city of Medan as the center of Mebidangro's economic, educational, industrial and trade activities.

2. The character of the Mebidangro implementing organs has not shown an orderly working mechanism, where the two main components of the character of the implementing organs, namely the SOP and the division of tasks / authorities between the provincial government and district / city governments as well as between district / city governments throughout the Mebidangro region do not exist. In the absence of SOPs and division of tasks, the character of the implementing organs is unable to produce the expected performance to ensure the successful implementation of the Mebidangro urban waste management program.

3. The Cooperation Agency uses an integrated management agency model. In the Integrated Management Institution model, the main activities in cooperation are managed by Provincial OPDs supported by City / Regency OPDs consisting of compulsory cooperation and voluntary cooperation, while the professional party selected by the regional head of the member through a fit and proper test is the head of the secretariat together and tasked with carrying out technical coordination between member regions in creating cooperative sectors. Structurally, the integrated institution is chaired by the Deputy Governor of North Sumatra with members of the Regents / Mayors at the policy level, while at the technical level it is filled by the District / City Secretary, related OPDs and Bappeda

\section{References}

Dewi, E. et al. (2018). Returning Government Policy for Poverty Reduction in Aceh. Budapest International Research and Critics Institute-Journal (BIRCI-Journal). P. 4149.

Handayani,Sri, Agus Suryono, M. Saleh Soeaidy. (2015) Implementasi Kebijakan Kerjasama Desa Melalui BKAD, Program Magister Ilmu Administrasi Publik, Universitas Brawijaya, Jurnal Ilmu Sosial Dan Ilmu Politik ISSN. 2442-6962 Vol. 4, No. 1 20, 2013

Indrawan, Rully dan R Poppy Yaniawati. (2014). Metodologi PenelitianKuantitatif, Kualitatif, dan Campuran, Refika Aditama, Bandung

Keban, Yeremias T. (2004). EnamDimensi Strategis Administrasi Publik: Konsep, Teori dan Isu. Yogyakarta: Gava Media.

Moleong, Lexy J. (1993). Metodologi Penelitian Kualitatif, Cetakan ke-4, PT Remaja Rosda Karya, Bandung. 
Perdana, A. A., et al. (2019). Society Response to Mobile Services on Mobile on The Road Investment Services and Integrated One-Stop Licensing Services in Tebing Tinggi City. Britain International of Humanties and Social Sciences (BIoHS) Journal, 44-52.

Pratikno (ed). (2007). Kerjasama Antar Daerah: Kompleksitas Dan Tawaran Format Kelembagaan, Jogja Global Media, Yogyakarta

Prawesti, Wening Jaksi. (2016). Kerjasama Antar Daerah dalam Pengelolaan

Sampah Tempat Pembuangan Akhir (TPA) Regional di Metropolitan Cirebon Raya. Prosiding Temu Ilmiah IPLBI 2016 hal.69-76.

Scott, W. Richard. (2004). Teori Kelembagaan. dalam Ensiklopedia Teori Sosial, George Ritzer, ed. Thousand Oaks, CA: Sage. Pp. 408-14

Surjandari,Isti, Akhmad Hidayatno, \& Ade Supriatna. (2009). Model Dinamis Pengelolaan Sampah Untuk Mengurangi Beban Penumpukan. Jurnal Teknik Industri, Vol. 11, No. 2, Desember 2009, hal. 134-147.

Undang-undang Nomor 23 Tahun 2014 Tentang Pemerintahan Daerah, Lembaran Negara Republik Indonesia Tahun 2014 Nomor 244

Undang-undang Nomor 18 Tahun 2008 Tentang Pengelolaan Sampah, Tambahan Lembaran Negara Republik Indonesia Nomor 4851

Undang-undang Nomor 26 Tahun 2007 tentang Penataan Ruang, Lembaran Negara Republik Indonesia Tahun 2007

Warsono, Hadi. (2009). Regionalisasi Dan Manajemen Kerjasama Antar Daerah (Studi Kasus Dinamika Kerjasama Antar Daerah Yang Berdekatan di Jawa Tengah), Disertasi, Program Doktor Ilmu Administrasi Negara,Yogyakarta, Universitas Gadjah Mada. 